\title{
Some Influences of Pancreatic Hormone upon the Lymph.
}

\author{
By
}

SHIGEHIRO KATSURA and KISHIRO KOZUKA.

(桂重 㳹) (小塚喜·四 郎)

(From Prof. T. Kumagai's Medical Clinic,

Tohoku Imperial University, Sendai.)

\section{Absence of Convulsions on Injecting Pancreatic Hormone after Excluding the Lympe.}

Previously $\mathrm{w}^{1)}$ reported the fact that in animals, the thoracic and the right lymphatic ducts of which have been bound with cannulas, thus excluding all the lymph from the body, the blood sugar falls after the injection of hormone, which is artificially drawn from the pancreas (insulin), just as low as in normal animals, and we said that this artificial pancreatic hormone is absorbed through the blood vessels, while in the normal physiological state the hormone comes from the pancreas only through the lymphatic ducts.

In these experiments we happened to observe that the animals in which the lymph was exclùded never fell into convulsions after the hormone injection. Now we wanted to know, if the convulsions are really absent even when the blood sugar falls exceedingly.

Adult rabbits were used for the test animals and starved for 24 hours. Using no narcosis, the animals were tied and the thoracic duct was bound with a cannula indirectly. The right lymphatic duct was often cut off at the same time.? After the operation the animals were untied and put into a large cage. The subcutaneous injection of the pancreatic hormone followed immediately or on the next day, when the influence of the tying upon the blood sugar should have ceased, and the blood sugar of the ear vein was estimated according to $\mathrm{Holb}_{0} \mathrm{ll}^{\prime} \mathrm{s}^{3}$ ) modification of Bang's method. The pancreatic hormone was prepared in our laboratory as has been described by Prof. Ku magai, Sato and Suzu-

1) S. Katsura and K. Kozuk a, Chugai Iji Shimpo, 1925, 44, 1219. (Jap.).

2) S. K at su ra, Tohoku Journ. of Exp. Med., 1924, 5, 294.

3) Holböll, Bioch. Zeitschr., 1921, 113, 200. 
$\mathrm{ki}^{\left.1)^{2}\right)}$ at the 20th and the 21st Japanese Congress of Internal Medicine. To state briefly, the pancreas is ground to a pulp, a double amount of $95 \%$ alcohol is added and the mixture filtered after 24 hours. The alcohol is then driven off at a low temperature, and this raw extract is mixed with $1 / 10$ volume of concentrated sulphuric acid and filtered; $1 / 5$ volume of carbolic acid added precipitates from this the potent hormone, whence the precipitate is dissolved again in weakly acidified distilled water. It was repeatedly examined and proved that 0.3 c.c. of the solution contains 1 rabbit unit, i.e., a dose enough to bring a rabbit of about 2000 grms. into convulsions within one or two hours, the blood sugar at this time being estimated at $0.035-0.025 \%$. The doses we used in our experiments fluctuated between $0.3-3.0$ c.c. (1-10 rabbit units).

We have made 8 experiments on rabbits with the thoracic fistula and 10 experiments on rabbits in which also the right lymphatic duct was cut off. We shall sketch here some of the experiments.

\section{Experiments.}

Rabbit 5. o, $2850 \mathrm{grms}$. 3. X. The thoracic cannula was indirectly inserted and the right Iymphatic duct was cut off; the lymph flowed freely. The operation lasted for $50^{\prime}$. The rabbit was allowed to remain till the next morning.

4. X., 18 hrs. after it had been left, the blood sugar was $0.153 \%$. 0.9 c.c. pancreatic hormone (1.3 R. U. per kilo) was injected subcutaneously. 5 hrs. after injection the blood sugar fell to $0.044 \%$. The rabbit was entirely normal and showed no change of attitude.

On the third day, 5. X., the blood sugar was found $0.119 \%$. 1.0 c.c. (1.42 R. U. per kilo), and after $2 \mathrm{hrs}$ again 0.6 c.c. pancreatic hormone ( 0.85 R. U. per kilo) was injected. Blood sugar after $4 \mathrm{hrs.} 0.033 \%$, after $6 \mathrm{hrs.} 0.024 \%$ and after $7 \mathrm{hrs.} 0.022 \%$. The rabbit remained all the while entirely calm and overcame the hypoglycemia.

Rabbit 7. ㅇ, $2300 \mathrm{grms}$. 25. II. Indirect thoracic cannula inserted and the right lymphatic duct cut off; the lymph flowed freely. The operation lasted for $1 \mathrm{hr} .45 \%$. Blood sugar before tying $0.106 \%$, after operation $0.212 \%$. $1 \mathrm{hr}$. after the rabbit had been untied 1.4 c.c. pancreatic hormone ( $2 \mathrm{R}$. U. per kilo) subcutaneously injected. Blood sugar $1 \mathrm{hr}$. after the injection $0.106 \%$, after $4 \mathrm{hrs.} 0.048 \%$; then again 0.6 c.c. hormone $(0.83 \mathrm{R}$. U. per kilo) injected. Blood sugar 5 hrs. after the lst injection $0.025 \%$; there was no change in the attitude of the rabbit. After $6 \mathrm{hrs}$. blood sugar $0.019 \%$; the rabbit was a little relaxed and lay in an abdominal position, but showed no sign of convulsion, even when irritated. After 6 hrs. $10^{\prime}$ it rose spontaneously, and began to walk. After $6 \mathrm{hrs} .45^{\prime}$ the attitude became normal. After $7 \mathrm{hrs}$. blood sugar $0.015 \%$, there was no sign of adynamy or of convulsions, and the rabbit was entirely calm.

On the next morning, 26 . II, $18 \mathrm{hrs}$. after the first hormone injection the blood sugar was found to be $0.102 \%$. Once more 1.0 c.c. hormone (1.45 R. U. per kilo), and after $1 \mathrm{hr}$. again 0.6 c.c. ( 0.83 R. U. per kilo) injected. After 2 hrs. blood sugar $0.037 \%$, after $3 \mathrm{hrs}$. $0.024 \%$; the state of the rabbit was not at all changed. After $3 \mathrm{hrs} .40^{\prime}$ it seemed a little weakened and relaxed, and when kicked, it fell over and moved its extremities slowly for a few seconds. It then became highly adynamic, the reflex of the cornea was lost, opistho-

1) T. K umag a i and H. Sato, Proc. of the Jap. Congr. Intern. Med., 1923, II, 205. (Jap.).

2) T. Kumagai and M. Suzuki, Ibid., 1924, 12, 980. (Jap.). 
tonos appeared, and after $3 \mathrm{hrs} .45^{\prime}$ it died. During this agonia the blood sugar was found to be $0.019 \%$.

Rabbit 9. of, 2600 grms. 1. III. Both the thoracic and the right lymphatic ducts were cut off. Duration of the operation $1 \mathrm{hr} .30 \%$. Blood sugar before tying $0.122 \%$, after operation $0.310 \% .18^{\prime}$ after the rabbit had been untied 1.5 c.c. pancreatic hormone ( 2 R. U. per kilo), and after $1 \mathrm{hr}$. again 0.8 c.c. hormone (1.02 R. U. per kilo) subcutaneously injected. Blood sugar $7 \mathrm{hrs}$. after the 1st injection $0.038 \%$, after $9 \mathrm{hrs.} 0.027 \%$; the rabbit remained quiet. After $9 \mathrm{hrs} .35^{\prime}$ it seemed a little uneasy, but no sign of convulsions appeared. After $10 \mathrm{hrs}$. it became highly adynamic, yet no convulsions took place, even when irritated by kicking. After $10 \mathrm{hrs} .37^{\prime}$ it remained motionless in an abdominal position, and the reflex of the cornea was lost. After 10 hrs. 42 the blood sugar was $0.023 \%$; thereupon the animal died quietly as if falling asleep.

Rabbit 10. ㅇ, 2100 grms. 1. III. the thoracic cannula was applied and the right Jymphatic duct was cut cff. Duration of the operation $1 \mathrm{hr}$. Blood sugar before tying $0.106 \%$, after operation $0.277 \%$. Immediately after the rabbit was untied 1.3 c.c. pancreatic hormone ( $2 \mathrm{R}$. U. per kilo) was injected. Blood sugar after $1 \mathrm{hr} .0 .116 \%$; again 0.65 c.c. (1 R.U. per kilo) injected. After 4 hrs. the blood sugar was $0.026 \%$; the rabbit remained calm. After 5 hrs. $0.022 \%$ : after taking the blood the rabbit became a little adynamic and then ran uneasily, but there were no convulsions. After $5 \mathrm{hrs} .16^{\prime}$ it ran again uneasily and fell down. After 6 hrs. the blood sugar was $0.031 \%$; the animal was considerably adynamic, but recovered after a while. After $6 \mathrm{hrs} .45^{\prime}$ a slight attack of convulsions took place, lasting for about $3^{\prime}$, but it soon recovered. After $7 \mathrm{hrs}$. blood sugar was $0.017 \%$; the rabbit ran, and then again became adynamic, but the convulsions did not occur again even when irritated by kicking. After $7 \mathrm{hrs} .8^{\prime}$ it fell down, gasping for air, stretched the hind extremities and difd without any more convulsions.

Rabbit 11. $\delta$, 1820 grms. 3. III. The lymphatic ducts on both sides were cut off. Duration of the operation $1 \mathrm{hr} .10^{\prime}$. Blood sugar before and after the operation $0.088 \%$ and $0.148 \%$ respectively. $10^{\prime}$ after the rabbit had been untied 1.6 c.c. pancreatic hormone ( 3 R.U. per kilo) injected. Blood sugar 3 hrs. after the injection $0.048 \%$, after $4 \mathrm{hrs} .0 .030 \%$, after 5 hrs. $0.028 \%$; the rabbit remained all the while entirely calm. Blood sugar after 6 hrs. $0.027 \%$; now highly adynamic, as though sleeping, but no sign of convulsions. After $6 \mathrm{hrs}$. $20^{\prime}$ it still remained quiet. After $6 \mathrm{hrs}$. 35' it suddenly stretched the extremities while in an abdominal position and remained about 1 , then falling on the right side and uttering a cry, died suddenly 6 hrs. $39^{\prime}$ after the injection. Blood sugar directly before death was $0.029 \%$.

Rabbit 8 . ㅇ, 1700 grms. 25.II. The rabbit was tied and just the same operation as before was carried out except that the V. cava sup. sin. was left unbound, so that the thoracic lymph flowed freely into the blood. Also the right side of the neck was prepared but the right lymphatic duct was left intact. Blood sugar before tying $0.092 \%$, after operation $0.126 \%$. 1 c.c. of pancreatic hormone (1.8 R. U. per kilo) injected subcutaneously. Blood sugar $1 \mathrm{hr}$. after the injection $0.035 \%$, after $2 \mathrm{hrs} .0 .031 \%$; the rabbit was a little adynamic and relaxed, and stretched the anterior extremities. Blood sugar after $2 \mathrm{hrs}$. $30^{\prime} 0.029 \%$; convulsions appeared and continued for $5^{\prime}$, after which adynamy followed. After $2 \mathrm{hrs}$. 37' the rabbit fell down, and after $2 \mathrm{hrs} .45^{\prime}$ severe convulsions again appeared. After 3 hrs. $30^{\prime}-40^{\prime}$ severe convulkions followed successively, the rabbit meanwhile rolling itself on the floor. After $3 \mathrm{hrs} .45^{\prime}$ it jumped up about 1 meter. After $3 \mathrm{hrs} .48^{\prime}-55^{\prime}$ extremely violent convulsions occurred. After 4 hrs. the animal was restored by the injection of glucose solution. 
Rabbit 14. ㅇ, 1750 grms. 9. III. Without any operation $1 \mathrm{mg}$ adrenalin was injected subcutaneously. Blood sugar before injection $0.115 \%$ and $1 \mathrm{hr}$. after injection $0.295 \%$; at once 0.6 c.c. pancreatic hormone (1.14 R. U. per kilo) was injected. Blood sugar 2 hrs. after the adrenalin injection $0.227 \%$; again 0.6 c.c. hormone injected. Blood sugar $3 \mathrm{hrs}$. after the adrenalin injection $0.128 \%$; again 0.6 c.c. hormone injected. After $4 \mathrm{hrs} .0 .083 \%$; again 0.6 c.c. hormone injected. Blood sugar after $5 \mathrm{hrs.} 0.038 \%$, after $6 \mathrm{hrs}$. $25^{\prime} 0.033 \%$; at that stage the rabbit became adynamic. After $6 \mathrm{hrs.} 33^{\prime}-38^{\prime}$ the rabbit lay in an abdominal position. After $6 \mathrm{hrs} .40^{\prime}-43^{\prime}$ convulsions appeared several times. After 6 hrs. $50^{\prime}$ severe convulsions followed. After $7 \mathrm{hrs.} 7^{\prime}$ again violent convulsions took place. Blood sugar after $7 \mathrm{hrs.} 18 / 0.027 \%$; again and again violent convulsions. Restored by glucose injection.

From these experiments we see that, when the lymph is excluded, the characteristic convulsions are entirely absent even though the blood sugar becomes lower than $0.03-0.02 \%$ after the hormone injection. Sometimes remarkable hypoglycemia recovers whilst the rabbits remain entirely calm, and sometimes the rabbits becomes seriously adynamic and die just as if falling asleep. Occasionally, they do not show an adynamic state, but suddenly fall down, move their extremities only for a few seconds, fall rapidly into opisthotonos, and uttering a cry, they expire. Now and then, especially when the lymph of the right lymphatic duct is not excluded, a slight attack of convulsions takes place during the course of hypoglycemia, but it consists of slow stretching and contracting motions of the extremities, lasting for a few minutes, and, once having ceased it does not happen again, and the animals afterwards remain calm. Such an attack is quite different from the serious, continuous convulsions which one usually observes after the hormone injection. Only in 1 of the 18 experiments did we meet attacks of rather serious convulsions; in this case, however, the lymph did not flow out sufficiently.

Incidentally we may say that in rabbits in which the same manipulation and operation were carried out except only that the flowing of the lymph into the blood was left intact, or again in rabbits, in which at first the adrenalin was injected and the blood sugar rose, the injection of the pancreatic hormone was always followed by serious, typical convulsions as in normal animals.

Consequently, the absence of convulsions in our present experiments must be due to the exclusion of the lymph from the body.

What the cause of this phenomenon may be, we may at present conclude that the hypoglycemia is not the sole, direct cause of the convulsions, but a certain condition closely connected with the lywph is necessary for the manifestation of convulsions. 


\section{Hypergitycemia Caused by the Lymph AFTER THE Hormone InJECTION.}

As a consequence of the fact mentioned above, we were led to the idea that it may be possible to provoke convulsions with the lymph flowing after the hormone injection. Accordingly, we subcutaneously injected the pancreatic hormone into a rabbit, and from the time of the injection collected the thoracic lymph and this was injected into the auricular vein of another rabbit. But the result was negative. We then collected the thoracic lymph from dogs before the injection of the pancreatic hormone and 2-6 hours after and injected the samples ( $40-80$ c.c.) into rabbits, at the same time estimating the blood sugar content. In 1 experiment the lymph was injected subcutaneously and in 2 intraperitoneally. Again we were unable to provoke any sign of convulsions.

Nevertheless, we happened to observe an interesting phenomenon during the course of our experiments.

Already there have been several researches with regard to the action of the normal lymph upon the carbohydrate metabolism. The fact was proved clearly by Profs. Kumagai and Osato, ${ }^{1}$ that in the normal physiological state the hormone of pancreas is carried through the thoracic duct. $S a 0^{2)}$ revealed the power of an extract, made from the lymph of normal dogs, to decrease the blood sugar of rabbits. Also in Biedl's ${ }^{3}$ ) recent experiments the normal lymph caused hypoglycemia. At first, we really expected that the artificial pancreatic hormone (insulin), when injected, would also appear mainly in the thoracic lymph, and the extract of the lymph after the hormone injection would cause a more intensive hypoglycemia than that of the normal lymph. But contrary to our expectation, 6 experiments all resulted in hyperglycemia, in one case even leading to the death of the rabbit. And this is another reason why we concluded that the artificial pancreatic hormone is not absorbed through the lymphatic ducts, as is the normal physiological hormone. We give here 4 examples. (Table I)

1) T. Ku magai and S. Osato, Tokohu Journ. of Exp. Med., 1920, 1, 153. (Jap.).

2) H. Sato, Proc. of the Jap. Congr. of Intern. Med., 1925, 12, 1078. (Jap.).

3) Bied l, Deut. med. Woch., 1923, 49, 937. 
TABLE

\begin{tabular}{|c|c|c|c|c|c|c|}
\hline \multicolumn{4}{|c|}{$\begin{array}{l}\text { Animals, from which lymph } \\
\text { is taken }\end{array}$} & \multicolumn{2}{|c|}{$\begin{array}{l}\text { 1. VI. Dog, } \delta, 8.1 \text { kilos. } \\
\text { Starved for } 1 \text { day. }\end{array}$} & $\begin{array}{l}\text { 8. VI. Dog, } \\
\text { Starved }\end{array}$ \\
\hline \multicolumn{4}{|c|}{ Operation } & \multicolumn{2}{|c|}{$\begin{array}{l}\text { Indirect thoracic fistula. } \\
\text { Duration } 1^{\text {hr }} 5^{\prime}\end{array}$} & $\begin{array}{l}\text { Indirect tho } \\
\text { Duration }\end{array}$ \\
\hline \multicolumn{4}{|c|}{ Amount of injected hormone } & \multicolumn{2}{|c|}{1.7 c.c. $(0.7$ R.U. per kilo $)$} & 3.75 c.c. $(0.7 \mathrm{R}$. \\
\hline \multicolumn{4}{|c|}{$\begin{array}{l}\text { Kind of extracted* lymph } \\
\text { Amount of extracted } \text { lymph }^{*}\end{array}$} & $\begin{array}{l}\text { Before hormone } \\
\text { injection } \\
20 \text { c.c. }\end{array}$ & $\begin{array}{l}\text { After hormone } \\
\text { injection } \\
20 \text { c.c. }\end{array}$ & $\begin{array}{l}\text { Before hormone } \\
\text { injection } \\
20 \text { c.c. }\end{array}$ \\
\hline \multicolumn{4}{|c|}{$\begin{array}{l}\text { Test animals } \\
\text { Locus of extract injection }\end{array}$} & $\begin{array}{l}\text { Rab. \& } \\
1050 \text { grms. } \\
\text { Subcutan. }\end{array}$ & $\begin{array}{l}\text { Rab. }+ \\
1400 \text { grms. } \\
\text { Subcutan. }\end{array}$ & $\begin{array}{l}\text { Rab. } \hat{o} \\
1440 \text { grms. } \\
\text { Subcutan. }\end{array}$ \\
\hline $\begin{array}{l}\frac{30}{30} \\
\vdots \\
0 \\
0 \\
0 \\
0 \\
0 \\
0 \\
0\end{array}$ & $\begin{array}{l}\text { Before } \\
1^{\text {br }} \text { aft } \\
2^{\text {brs }} \\
3^{\text {hrs }} " \\
4^{\text {hrs }} \\
5^{\text {hrs }} \\
6^{\text {hrs }} "\end{array}$ & $\begin{array}{l}\text { act } \\
\text { tra } \\
" 1 \\
" \\
"\end{array}$ & $\begin{array}{l}\text { ction } \\
\text { jection } \\
" \\
" \\
" \\
" \\
"\end{array}$ & $\begin{array}{l}0.099 \\
0.093 \\
0.084 \\
0.093 \\
0.096\end{array}$ & $\begin{array}{l}0.080 \\
0.100 \\
0.100 \\
0.095 \\
0.094 \\
\\
0.095\end{array}$ & $\begin{array}{l}0.085 \\
0.079 \\
0.083 \\
0.085 \\
0.082\end{array}$ \\
\hline \multicolumn{4}{|c|}{ Coeff. of changes of blood sugar } & $-16 \%$ & $+25 \%$ & $-7 \%$ \\
\hline
\end{tabular}

* The extraction of lymph is made as follows :-3 volumes of acidified alcohol ( 1 ture filtered; from the filtrate the alcohol is evaporated at a low temperature and the

TABLE II.

\begin{tabular}{|c|c|c|c|c|c|c|}
\hline \multicolumn{4}{|c|}{$\begin{array}{l}\text { Animals, from which lymph } \\
\text { is taken }\end{array}$} & \multicolumn{2}{|c|}{$\begin{array}{l}\text { 13. XI. Dog, o, } 13.0 \text { kilos. } \\
\text { Starved for } 4 \text { days }\end{array}$} & $\begin{array}{l}\text { 15. XII. Dog, } \\
\text { Starved }\end{array}$ \\
\hline \multicolumn{4}{|c|}{ Operation } & \multicolumn{2}{|c|}{$\begin{array}{l}\text { Direct thoracic fistula. } \\
\text { Duration } 1^{\text {hr }} 5 \text {. }\end{array}$} & $\begin{array}{r}\text { Indirect tho } \\
\text { Durati }\end{array}$ \\
\hline \multicolumn{4}{|c|}{ Amount of injected hormone } & \multicolumn{2}{|c|}{4.0 c.c. (1.0 R.U. per kilo) } & 4 c.c. $(1.0 \mathrm{R}$. \\
\hline \multicolumn{4}{|c|}{$\begin{array}{l}\text { Kind of injected Iymph } \\
\text { Amount of injected Jymph }\end{array}$} & $\begin{array}{l}\text { Before hormone } \\
\text { injection } \\
10 \text { c.c. }\end{array}$ & $\begin{array}{l}\text { After hormone } \\
\text { injection } \\
20 \text { c.c. }\end{array}$ & $\begin{array}{l}\text { Before hormone } \\
\text { injection } \\
40 \text { c.c. }\end{array}$ \\
\hline \multicolumn{4}{|c|}{$\begin{array}{l}\text { Test animals } \\
\text { Locus of lymph injection }\end{array}$} & $\begin{array}{l}\text { Rab. } \delta \\
1300 \text { grms. } \\
\text { Intraperit. }\end{array}$ & $\begin{array}{l}\text { Rab. } \delta, \\
1400 \text { grms. } \\
\text { Intraperit. }\end{array}$ & $\begin{array}{l}\text { Rab. }, \\
1380 \text { grms. } \\
\text { Subcutan. }\end{array}$ \\
\hline 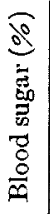 & $\begin{array}{l}\text { Before } \\
1^{\text {hr afte }} \\
2^{\text {hrs }}, \\
3^{\text {hrs }} " \\
4^{\text {brs }} " \\
5^{\text {hrs }} " \\
6^{\text {brs }} "\end{array}$ & $\begin{array}{l}\text { ph } \\
" \\
" \\
"\end{array}$ & $\begin{array}{l}\text { jection } \\
" \\
" \\
" \\
" \\
"\end{array}$ & $\begin{array}{l}0.094 \\
0.083 \\
0.077 \\
0.075 \\
0.055 \\
0.080 \\
0.084\end{array}$ & $\begin{array}{l}0.085 \\
0.174 \\
0.195 \\
0.227 \\
0.224 \\
0.179 \\
0.176\end{array}$ & $\begin{array}{l}0.091 \\
0.073 \\
0.070 \\
0.063 \\
0.094 \\
0.100 \\
0.098\end{array}$ \\
\hline \multicolumn{4}{|c|}{ Coeff. of changes of blood sugar } & $-42 \%$ & $+266 \%$ & $-31 \%$ \\
\hline
\end{tabular}


I.

\begin{tabular}{|c|c|c|c|c|}
\hline $\begin{array}{l}\text { o, } 15.5 \text { kilos. } \\
\text { for } 3 \text { days. }\end{array}$ & \multicolumn{2}{|c|}{$\begin{array}{l}\text { 6. VII. Dog, } \hat{\delta}, 7.9 \text { kilos. } \\
\text { Starved for } 2 \text { days. }\end{array}$} & \multicolumn{2}{|c|}{$\begin{array}{l}\text { 18. IX. Dog, } \hat{~}, 9.5 \text { kilos. } \\
\text { Starved for } 1 \text { day. }\end{array}$} \\
\hline $\begin{array}{l}\text { racic fistula. } \\
1^{\text {br } 14} .\end{array}$ & \multicolumn{2}{|c|}{$\begin{array}{l}\text { Direct thoracic fistula. } \\
\text { Duration } 1^{\mathrm{br}} 50^{\prime}\end{array}$} & \multicolumn{2}{|c|}{$\begin{array}{l}\text { Direct thoracic fistula. } \\
\text { Duration } 1^{\text {br }} 20^{\prime}\end{array}$} \\
\hline U. per kilo) & \multicolumn{2}{|c|}{3.5 c.c. (1.4 R.U. per kilo) } & \multicolumn{2}{|c|}{2.0 c.c. $(0.7$ R.U. per kilo) } \\
\hline $\begin{array}{l}\text { After hormone } \\
\text { injection } \\
20 \text { c.c. }\end{array}$ & $\begin{array}{l}\text { Before hormone } \\
\text { injection } \\
18 \text { c.c. }\end{array}$ & $\begin{array}{l}\text { After hormone } \\
\text { injection } \\
17 \text { c.c. }\end{array}$ & $\begin{array}{c}\text { Before hormone } \\
\text { injection } \\
15 \text { c.c. }\end{array}$ & $\begin{array}{c}\text { After hormone } \\
\text { injection } \\
21 \text { c.c. }\end{array}$ \\
\hline $\begin{array}{l}\text { Rab. } \delta, \\
1300 \text { grms. } \\
\text { Subcutan. }\end{array}$ & $\begin{array}{l}\text { Rab. } \delta, \\
1200 \text { grms. } \\
\text { Subcutan. }\end{array}$ & $\begin{array}{l}\text { Rab. } \delta, \\
1300 \text { grms. } \\
\text { Subcutan. }\end{array}$ & $\begin{array}{l}\text { Rab. } \delta, \\
1740 \text { grms. } \\
\text { Subcutan. }\end{array}$ & $\begin{array}{l}\text { Rab. } \delta, \\
1600 \text { grms. } \\
\text { Subcutan. }\end{array}$ \\
\hline $\begin{array}{l}0.094 \\
0.117 \\
0.119 \\
0.127 \\
0.110 \\
\\
0.092\end{array}$ & $\begin{array}{l}0.080 \\
0.081 \\
0.080 \\
0.078 \\
0.075 \\
\\
0.077\end{array}$ & $\begin{array}{l}0.090 \\
0.130 \\
0.122 \\
0.115 \\
0.109 \\
0.094\end{array}$ & $\begin{array}{l}0.082 \\
0.087 \\
0.087 \\
0.095 \\
0.100 \\
0.097 \\
0.094\end{array}$ & $\begin{array}{l}0.099 \\
0.148 \\
0.159 \\
0.182 \\
0.194 \\
0.201 \\
\text { Died }\end{array}$ \\
\hline$+35 \%$ & $-6 \%$ & $+42 \%$ & $+22 \%$ & $+210 \%$ \\
\hline
\end{tabular}

c.c. conc. sulphuric acid in 1000 c.c. $95 \%$ alcohol) is added to the lymph and the mixpart soluble in ether is driven off in a separating funnel.

\begin{tabular}{|c|c|}
\hline $\begin{array}{l}\text { 9, } 12.4 \text { kilos. } \\
\text { for } 1 \text { day. }\end{array}$ & $\begin{array}{l}\text { 18. I. Dog, }, 130 \text { kilos. } \\
\text { Starved for } 1 \text { day. }\end{array}$ \\
\hline $\begin{array}{l}\text { racic fistula } \\
\text { on } 50^{\prime} \text {. }\end{array}$ & $\begin{array}{l}\text { Direct thoracic fistula } \\
\text { Duration } 2^{\text {brs }}\end{array}$ \\
\hline U. per kilo) & 6 c.c. $(1.5$ R.U. per kilo) \\
\hline $\begin{array}{l}\text { After hormone } \\
\text { injection } \\
50 \text { c.c. }\end{array}$ & $\begin{array}{l}\text { After hormone } \\
\text { injection } \\
25 \text { c.c. }\end{array}$ \\
\hline $\begin{array}{l}\text { Rab. } \%, \\
1850 \text { grms. } \\
\text { Subcutan. }\end{array}$ & $\begin{array}{l}\text { Rab. } 9 \text {, } \\
1600 \text { grms. } \\
\text { Intraperit. }\end{array}$ \\
\hline $\begin{array}{l}0.096 \\
0.106 \\
0.094 \\
0.095 \\
0.096 \\
-.097\end{array}$ & $\begin{array}{c}0.089 \\
0.108 \\
0.113 \\
0.124 \\
0.115 \\
\overline{0.106}\end{array}$ \\
\hline$+10 \%$ & $+40 \%$ \\
\hline
\end{tabular}

Also in our present experiments, in which we injected the lymph collected after the hormone injection with the purpose of provoking convulsions, we saw, instead of convulsions, a remarkable elevation of the blood sugar (Table II).

Meanwhile, the lymph taken from six of the eight dogs before the injection of the pancreatic hormone, and from one in which no injection had been made, either extracted or in the raw form, caused a depression of the blood sugar to a certain degree, as our predecessors have proved already (Tables I \& II).

Briefly, then, due to the injection of the pancreatic hormone, the 
lymph undergoes a change such as to cause hyperglycemia, while the normal lymph has a power to cause hypoglycemia.

\section{Changes in Some Chemical Constituents Following THE HORMONE INJECTION.}

Whatever the reason may be for the hyperglycemia described above, it is urgent that the changes of the lymph after the hormone injection be carefully investigated, especially as there has been, so far as we are aware, very little published regarding this problem. In Meyer-Bisch, Günthe $r$ and Bock's ${ }^{1)}$ experiments the amount, refractometric index, sugar and some of the inorganic salts are examined. We undertook first of all to study the changes in the quantities of some of the organic substances in the lymph after the hormone injection: The sugar, the total and residual nitrogen, and the fat and lipoids.

TABLE

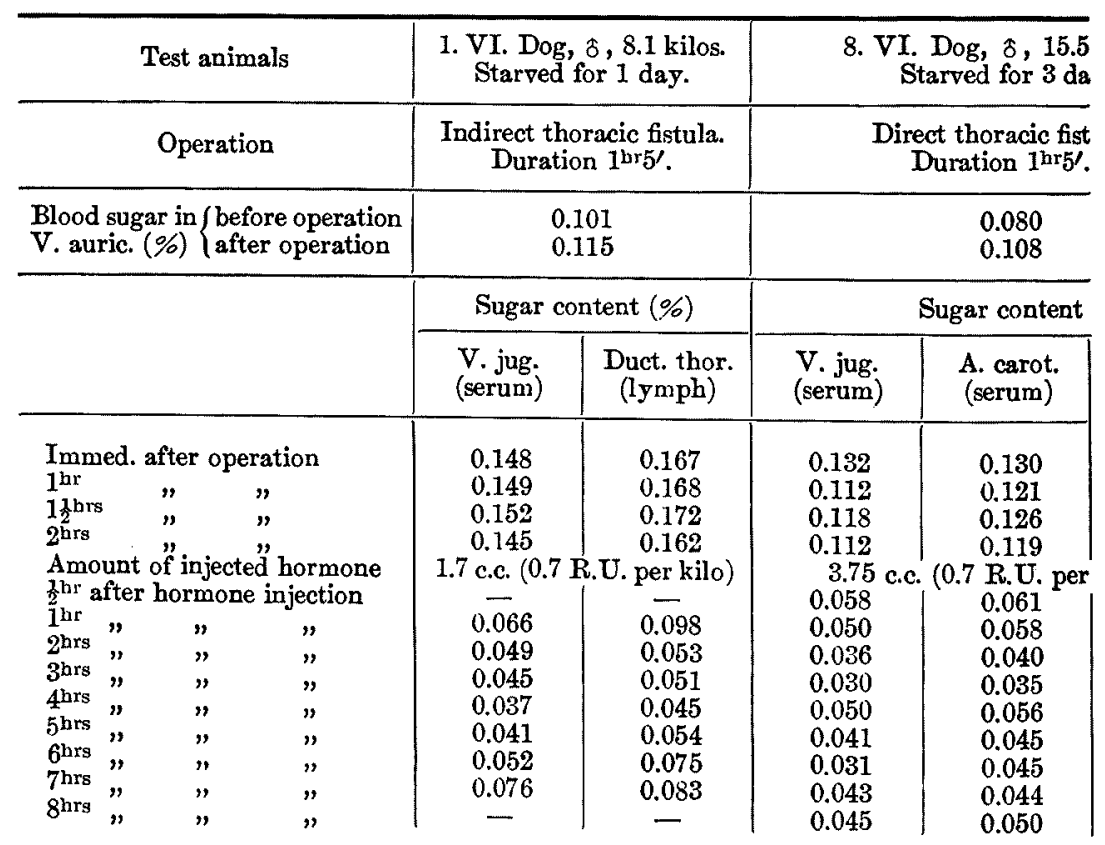

1) Meyer-Bisch, Günther and Bock, Pflüger's Archiv, 1926, 211, 341. 
Dogs were used for the test animals. After starvation for 1-4 days they were tied without narcosis and the fistula of the thoracic duct was applied, in the majority of the cases, directly. The pancreatic hormone was injected subcutaneously in the epigastric region in a dose of 1-1.5 rabbit units per kilo. The determination of the blood sugar was made according to the method of Bang modified by Holböll,1) the nitrogen by the halfmicro-Kijldahl method improved by $P$ incussen, ${ }^{2)}$ while the fatty acid and the cholesteroI were estimated after the method of Bloor, Pelkan and Allen,3) and the lecithin after that of Bloor.4)

As to the sugar content of the lymph, one of us (S. Katsura $)^{5)}$ had formerly made a close examination and reported that the sugar content in the neck lymph and in the carotid serum is always the same, while the sugar of the thoracic lymph is always a little lower than that of the serum of the liver vein, and is very closely related to the latter. Even when the sugar content fluctuates conspicuously, the serum sugar of the liver vein holds an approximate ratio of 1.04 to the lymph sugar of the thoracic duct.

III.

\begin{tabular}{|c|c|c|c|c|c|}
\hline $\begin{array}{l}\text { kilos. } \\
\text { ys. }\end{array}$ & \multicolumn{3}{|c|}{$\begin{array}{l}\text { 6. VII. Dog, } \delta, 7.9 \text { kilos. } \\
\text { Starved for } 2 \text { days. }\end{array}$} & \multicolumn{2}{|c|}{$\begin{array}{l}\text { 24. X. Dog, \$, } 9.5 \text { kilos. } \\
\text { Starved for } 1 \text { day. }\end{array}$} \\
\hline \multirow[t]{2}{*}{ ula. } & \multicolumn{3}{|c|}{$\begin{array}{l}\text { Indirect thoracic fistula. } \\
\text { Duration } 1^{\mathrm{br}} 50^{\prime}\end{array}$} & \multicolumn{2}{|c|}{$\begin{array}{l}\text { Direct thoracic fistula. } \\
\text { Duratioh } 1^{\text {hr }} 40^{\prime}\end{array}$} \\
\hline & \multicolumn{3}{|c|}{$\begin{array}{l}0.081 \\
0.086\end{array}$} & \multicolumn{2}{|c|}{0.096} \\
\hline$(\%)$ & \multicolumn{3}{|c|}{ Sugar content $(\%)$} & \multicolumn{2}{|c|}{ Sugar content $(\%)$} \\
\hline $\begin{array}{l}\text { Duct. thor. } \\
\text { (lymph) }\end{array}$ & $\begin{array}{l}\text { V. jug. } \\
\text { (serum) }\end{array}$ & $\begin{array}{l}\text { A. carot. } \\
\text { (serum) }\end{array}$ & $\begin{array}{l}\text { Duct. thor. } \\
\text { (lymph) }\end{array}$ & $\begin{array}{l}\text { V. auric. } \\
\text { (blood) }\end{array}$ & $\begin{array}{l}\text { Duct. thor. } \\
\text { (lymph) }\end{array}$ \\
\hline 0.145 & 0.099 & 0.097 & 0.123 & - & - \\
\hline 0.135 & 0.100 & 0.108 & 0.121 & 0.144 & - \\
\hline 0.143 & - & - & - & 0.119 & 0.138 \\
\hline 0.142 & 0.094 & 0.096 & 0.122 & 0.106 & 0.125 \\
\hline kilo) ${ }_{0.086}$ & 3.5 & 1.4 R.U. & kilo) & 2.3 c.c. $(0$. & . per kilo) \\
\hline 0.086 & 0.052 & 0.059 & 0.097 & - & - \\
\hline 0.067 & 0.046 & 0.054 & 0.067 & 0.067 & 0.068 \\
\hline 0.059 & 0.044 & 0.045 & 0.064 & 0.050 & 0.048 \\
\hline 0.045 & 0.042 & 0.056 & 0.058 & 0.041 & 0.040 \\
\hline 0.060 & 0.045 & 0.050 & 0.052 & 0.038 & 0.030 \\
\hline $\begin{array}{l}0.050 \\
0.053\end{array}$ & 0.046 & 0.042 & 0.052 & 0.035 & 0.025 \\
\hline $\begin{array}{l}0.053 \\
0.060\end{array}$ & 0.032 & 0.038 & 0.058 & 0.034 & 0.026 \\
\hline 0.070 & 0.055 & 0.059 & $\begin{array}{l}0.006 \\
0.067\end{array}$ & - & 二 \\
\hline
\end{tabular}

1) Holböll, 1. c.

2) Pincussen, Mikromethodik, Leipzig 1923, $61 \& 68$.

3) Bloor, Pelk an and Allen, Journ. of Biol. Chem., 1922, 52, 191.

4) B lo or, Ibid., 1918, 36, 33.

5) S. Katsura, Tohoku Journ. of Exp. Med., 1926, 7, 382. 
Now, after the injection of the pancreatic hormone, the sugar of the thoracic lymph decreases almost parallel to that of the jugular or carotid serum, keeping, in the majority of cases, a little higher value than the latter. Accordingly, we may assume that during the action of the pancreatic hormone the serum sugar of the liver vein is nearly always higher than that of the peripheral arteries. Only in 1 case out of $7 \mathrm{did}$ the thoracic lymph sugar fell lower than the blood sugar of the auricular vein. In general, these results accord with those obtained by Shiroshita. ${ }^{1)}$ Some examples of our experiments are given here (Table III).

As to the nitrogen content, the total nitrogen diminishes. a little, and the residual nitrogen seems to increase slightly after the hormone injection,

TABLE

13. XI. Dog, ऊ, 13.0 kilos, starved for 4 days. Direct

\begin{tabular}{|c|c|c|c|c|c|}
\hline & & \multicolumn{4}{|c|}{ Blood } \\
\hline & & Sugar & Cholesterol & Fatty acid & Lecithin \\
\hline \multirow{2}{*}{\multicolumn{2}{|c|}{$\begin{array}{l}\text { Before operation } \\
\text { Before hormone injection }\end{array}$}} & $\begin{array}{l}0.087 \\
0.103\end{array}$ & 112 & 362 & 336 \\
\hline & & 4 c.c. par & reatic hormo & (1 R.U. per & lo) subcutar \\
\hline \multicolumn{2}{|c|}{$\frac{1}{2} \mathrm{hr}$ after hormone injection } & 0.047 & 109 & $341^{\mathrm{T}}$ & 328 \\
\hline $3 \frac{\mathrm{hrs}}{3}$ & $" \quad " \quad$ & 0.032 & 111 & 342 & 328 \\
\hline $\begin{array}{l}5^{\mathrm{hrs}} \\
7^{\mathrm{hurs}}\end{array}$ & $" \quad "$ & $\begin{array}{l}0.034 \\
0.026\end{array}$ & $\overline{108}$ & $\overline{390}$ & $\overline{300}$ \\
\hline
\end{tabular}

The blood was taken from the ear vein before the operation, and after the fatty acid and lecithin were estimated in the whole blood, the nitrogen in the blood thoracic lymph serum. Such was rather inevitable in the present experiments. The The amount of lymph is calculated in c.c. per $10^{\prime}$. The same notion is applied also

TABLE

15. XI. Dog, ㅇ, 12.4 kilos, starved for 1 day. Direct

\begin{tabular}{|c|c|c|c|c|c|c|}
\hline & & & \multicolumn{4}{|c|}{ Blood } \\
\hline & & & Sugar & Cholesterol & Fatty acid & Lecithin \\
\hline \multicolumn{3}{|c|}{$\begin{array}{l}\text { Before operation } \\
\text { Before hormone injection }\end{array}$} & $\begin{array}{l}0.085 \\
0.088\end{array}$ & 153 & 445 & 428 \\
\hline \multirow{2}{*}{\multicolumn{3}{|c|}{$1^{\text {hr }}$ after hormone injection }} & 4 c.c. I & eatic horm & R.U. per & lo) subcutan. \\
\hline $3^{\text {hins }}$ & & & 0.042 & $\begin{array}{l}145 \\
755\end{array}$ & $420^{\circ}$ & 408 \\
\hline $5^{\mathrm{krss}}$ & " & $"$ & 0.045 & $15 b$ & 464 & 432 \\
\hline $7 \mathrm{hrs} "$ & $"$ & $"$ & 0.060 & 147 & 424 & 416 \\
\hline $10^{\text {hrs }} "$, & $"$ & $"$ & 0.078 & 142 & $\begin{array}{l}402 \\
456\end{array}$ & $\begin{array}{l}428 \\
424\end{array}$ \\
\hline
\end{tabular}

1) R. Shirosh ita, Hokkaido Igaku Zasshi, 1925, 3, 71 (Jap.). 
if compared with the control experiments, but these changes are not very conspicuous (Tables IV \& V).

The most interesting and remarkable changes are those of the fat and lipoids. There have been already some researches regarding the influence of insulin upon the fat metabolism, but so far as we are aware, nobody has investigated the fat in the lymph from this point of view. Now the fatty acid, the cholesterol and the lecithin in the thoracic lymph all begin to increase within 3 hours after the hormone is injected and reach their maximal hights 4-5 hours after the injection. This increase is often more than $100 \%$, and the marked turbidity of the thoracic lymph can be distinguished even with the naked eye. These high contents continue, although

\section{IV.}

thoracic fistula applied. Duration of operation $1^{\mathrm{hr}} \mathbf{5}^{\prime}$.

\begin{tabular}{c|c|c|c|c|c|c}
\hline & \multicolumn{6}{|c}{ Lymph } \\
\hline Residual N & Amount & Cholesterol & Fatty acid & Lecithin & Residual N & Total N \\
\cline { 3 - 7 } & & & & & & \\
65 & 4.4 & 63 & 342 & 120 & 35.7 & 380 \\
87 & 2.5 & 66 & 348 & 136 & 39.0 & 415 \\
61 & 3.2 & 72 & 494 & 200 & 40.5 & 433 \\
72 & 3.0 & 121 & 892 & 284 & 42.0 & 530 \\
67 & 3.2 & 105 & 608 & 216 & 42.0 & -
\end{tabular}

operation from the jugular vein on the right side. The blood sugar, cholesterol, serum. All the researched constituents were estimated on the other side in the content of sugar is expressed in $\%$, of the other constituents in mgrm. per 100 c.c. in the following tables.

V.

thoracic fistula applied. Duration of operation $50^{\prime}$.

\begin{tabular}{c|c|c|c|c|c|c}
\hline & \multicolumn{6}{|c}{ Lymph } \\
\hline Residual N & Amount & Cholesterol & Fatty acid & Lecithin & Residual N & Total N \\
\hline & & & & & & \\
32.8 & 3.0 & 63 & 252 & 144 & 32.1 & 472 \\
& & & & & & \\
34.6 & 3.3 & 74 & 298 & 152 & 33.6 & 443 \\
36.7 & 3.5 & 109 & 417 & 184 & 36.8 & 392 \\
35.7 & 2.1 & 114 & 516 & 256 & 35.3 & 368 \\
31.8 & 1.4 & 103 & 498 & 232 & 33.9 & 349 \\
37.8 & 1.8 & 85 & 468 & 208 & 33.9 & 373
\end{tabular}


slowly decreasing, for more than 10 hours. As to this phenomenon there was no single exception in 7 experiments. In the jugular blood the fat and the lipoids undergo no such changes. Here are given 2 experiments. (Tables IV \& V). As is proved by Shiroshita, 1) the lymph flow diminishes after pancreatic hormone, but the increase of the fat seems not to be dependent on this diminution of the lymph amount.

We have no space here to enter into the detailed significance of this phenomenon, but we believe we have revealed a new fact regarding the influence of pancreatic hormone upon the fat metabolism. Of course the cause of the hyperglycemia by the lymph after the hormone injection is not yet explained. Further investigations into the character of the lymph after the hormone injection are necessary.

\section{The Action of Adrenalun upon the Contents of the}

Fat and Lipoms in The LYMPh.

As to the antagonistic actions of pancreatic hormone and adrenalin, $\mathrm{Obara}{ }^{2)}$ made a detailed research and reported, that their antagonism

TABLE

19. I. Dog, ô, 9.4 kilos, starved for 1 day. Indirect

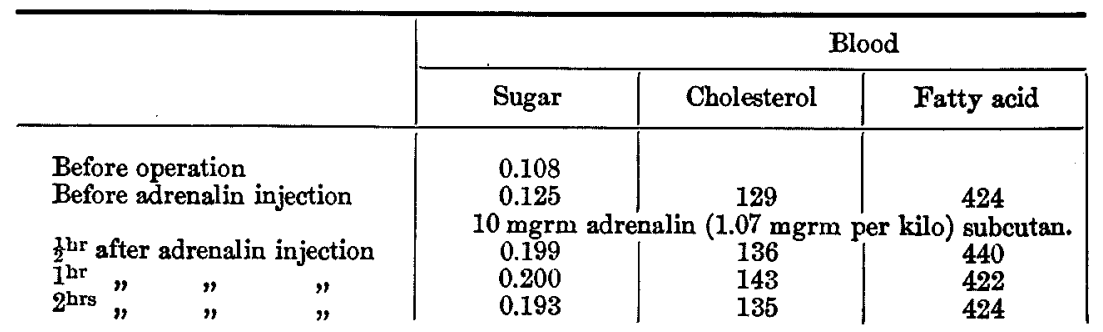

presents itself only with regard to the glycogen and the blood sugar. But in his experiments the influences of both drugs upon the fat metabolism were not taken into consideration. Some authors declare that insulin and adrenalin are antagonistic also with regard to the influence upon the fat metabolism, though the directions of their results are not concordant. ${ }^{3 \text { ) }}$

As we had proved the maked effect of pancreatic hormone upon the

1) Shiroshita, 1.c.

2) Ohara, Tohoku Journ. of Exp. Med, 1925, 6, 213.

3) Details of the literature regarding this problem are given by $\mathrm{Ok} \mathrm{u}$, Naibumpitsugaku Zasshi, 1925, 1, 435 \& 566. (Jap.). 
fat content in the thoracic lymph, we considered it interesting to inquire into the influence of adrenalin upon the latter.

Dogs were prepared as in cases of the pancreatic hormone, and adrenalin was injected in a dose of 15-20 mgrm. per kilo.

After the injection of the adrenalin, all the fat and lipoids in the thoracic lymph undergo indeed a remarkable change: within 1/2-1 hour, the lymph becomes suddenly clear, and the amounts of the fatty acid, the cholesterol and the lecithin are often reduced to less than one half of the original value. (Table VI).

When pancreatic hormone and adrenalin are injected one after the other, a marvelous alternation is exhibited. The highest fat and lipoid contents, attained in 3-5 hours after the pancreatic hormone injection, are replaced, if at this time adrenalin is given, within 1/2-1 hour by the lowest contents. On the other hand, the lymph, which becomes very clear if adrenalin is injected, will, if pancreatic hormone is then injected, become again strongly turbid after the lapse of 3-5 hours. (Tables VII \& VIII).

As a matter of fact, adrenalin decreases the content of the fat and lipoids in the thoracic lymph, exactly contrary to pancreatic hormone.

VI.

thoracic fistula applied. Duration of operation $1^{\text {hr23' }}$.

\begin{tabular}{c|c|c|c|c}
\hline & \multicolumn{4}{|c}{ Lymph } \\
\hline Lecithin & Amount & Cholesterol & Fatty acid & Lecithin \\
\hline & & & & \\
408 & 1.15 & 91 & 480 & 240 \\
400 & 1.27 & 77 & 406 & 216 \\
400 & 1.94 & 62 & 287 & 152 \\
416 & 1.85 & 67 & 303 & 184
\end{tabular}

5. The Contents of the Fat and Lipoids in the Thoracic Lymph of Control Animals.

The thoracic lymph of starved animals left for several hours before injection or in which no injection is made, indicates also a certain fluctuation of the contents of the fatty acid and lipoids. Sometimes they increase from the beginning gradually, sometimes they at first diminish and then increase, although far less intensive than in the cases of injection. Out of the 4 experiments we give here two. (Tables VIII \& IX). 
TABLe

8. II. Dog, $9,13.5$ kilos, starved for 1 day. Direct

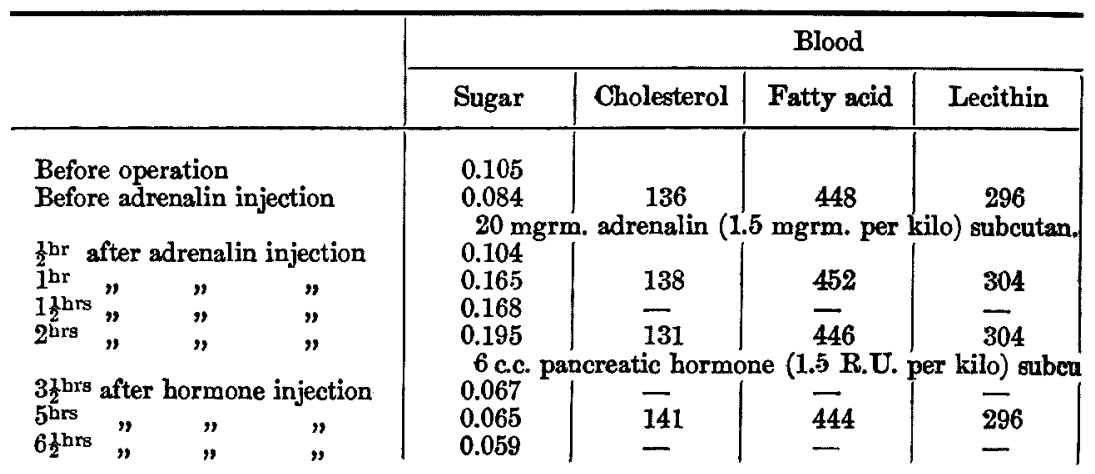

TABLE

19. III. Dog, 우 , 6.5 kilos, starved for 1 day. Indirect

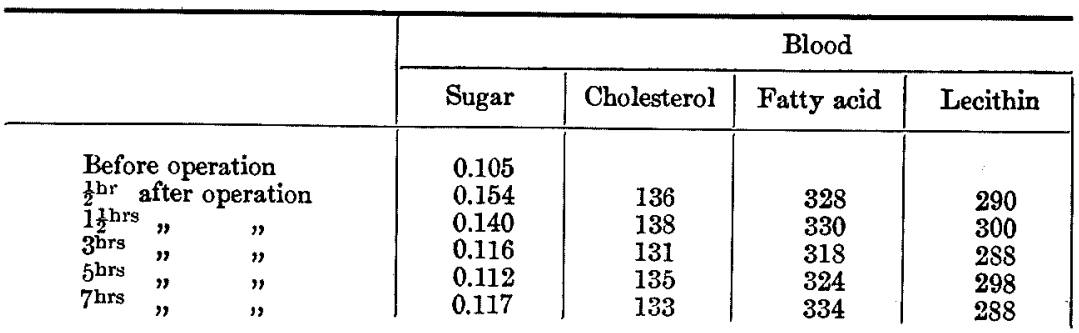

TABLE IX.

8. V. Dog, o, 11.0 kilos, starved for 2 days. Direct thoracic fistula Duration of operation $50 \%$

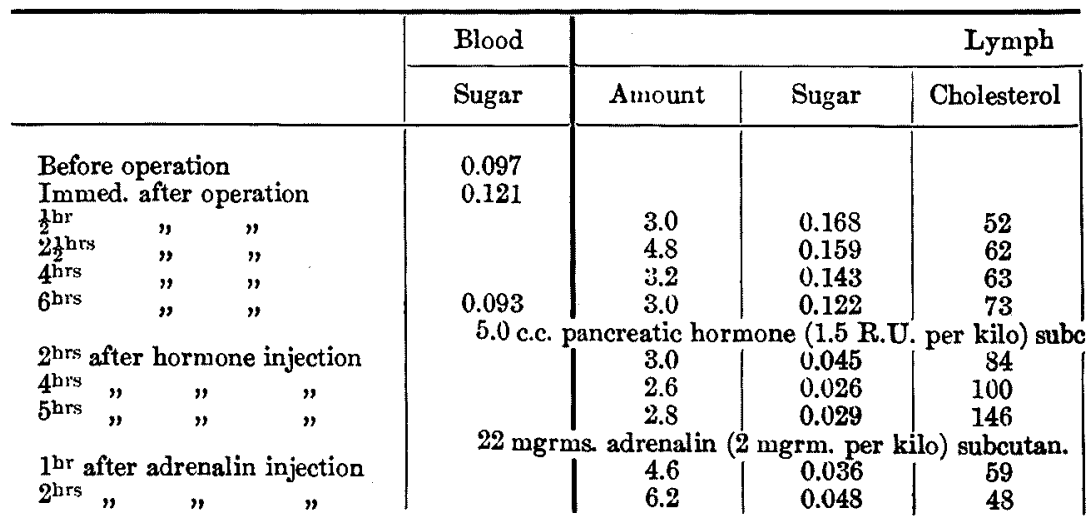


VII.

thoracic fistula applied. Duration of operation $2^{\text {hrs }}$.

\begin{tabular}{c|c|c|c|c|c|c}
\hline & \multicolumn{6}{|c}{ Lymph } \\
\cline { 2 - 7 } Residual N & Amount & Cholesterol & Fatty acid & Lecithin & Residual N & Total N \\
\hline & & & & & & \\
31.5 & 1.46 & 78 & 544 & 208 & 18.9 & 726 \\
& & & & & & \\
26.8 & 3.44 & 85 & 612 & 208 & 21.0 & 734 \\
- & 3.85 & 54 & 335 & 120 & 19.9 & 616 \\
30.8 & 3.00 & 52 & 320 & 112 & 20.3 & 638 \\
$\tan$. & 5.40 & 51 & 312 & 120 & 21.7 & 645 \\
30.1 & 1.75 & 76 & 548 & 232 & 22.4 & 736 \\
32.7 & 2.18 & 69 & 444 & 192 & 21.7 & 716 \\
& 1.96 & 68 & 440 & 184 & 21.0 & 710
\end{tabular}

VIII.

thoracic fistula applied. Duration of operation $1^{\text {br }} 10^{\prime}$.

\begin{tabular}{c|c|c|c|c|c|c}
\hline & \multicolumn{6}{|c}{ Lymph } \\
\cline { 2 - 6 } Residual N & Amount & Cholesterol & Fatty acid & Lecithin & Residual N & Total N \\
\hline & & & & & & \\
38.2 & 3.15 & 67 & 384 & 200 & 29.7 & 671 \\
39.2 & 2.17 & 76 & 416 & 224 & 34.3 & 733 \\
36.4 & 1.65 & 79 & 548 & 248 & 31.5 & 688 \\
35.0 & 1.75 & 90 & 624 & 272 & 31.5 & 693 \\
36.4 & 1.00 & 83 & 564 & 240 & 33.9 & 617
\end{tabular}

applied.

As we used animals which had been starved for 30-50 hours, we may exclude the possibility of absorption from the intestinal tract. Such a fluctuation of the fat and lipoid contents in the

\begin{tabular}{c|c}
\hline Fatty acid & Lecithin \\
\hline & \\
& \\
376 & 182 \\
489 & 204 \\
494 & 200 \\
508 & 222 \\
utan. & \\
512 & 226 \\
695 & 240 \\
840 & 318 \\
420 & \\
304 & 216 \\
& 132
\end{tabular}
thoracic lymph of the normal animals might even lead us to suspect whether or not the results after the injection of the pancreatic hormone or adrenalin be merely accidental.

However, when we inspect the results in these control experiments more minutely, we may find that such animals, in which the fat and lipoid contents of the lymph diminish for a while, are those in which the blood sugar increases remarkably by tying and the operation, and at the same 
time, that the gradual increase of the fat contents is accompanied by the gradual depression of the blood sugar. Hence it cannot be a mere accident, that the fat and lipoids increase after the injection of pancreatic hormone, and decrease after the injection of adrenalin.

\section{Summary}

1. When the lymph is excluded from the body, the convulsions after the injection of pancreatic hormone are either entirely absent or suppressed to a remarkable degree. The hypoglycemia is therefore not the sole, direct cause of the convulsions, but a certain condition which is closely related to the lymph is necessary for the manifestation of the convulsions.

2. After the injection of pancreatic hormone, the thoracic lymph undergoes a change so as to cause hyperglycemia, while the normal lymph has a power to cause hypoglycemia.

3. The sugar of the thoracic lymph falls after the injection of pancreatic hormone nearly parallel with that of the carotid serum, holding a little higher content than the latter. The fat and lipoids in the thoracic lymph increase very distinctly 4-5 hours after the hormone injection. As to the nitrogen content there are no conspicuous changes.

4. 1/2-1 hour after its injection, adrenalin decreases the amount of the fat and lipoids in the thoracic lymph, just contrary to pancreatic hormone.

5. Also in normal starved animals the contents of the fat and lipoids in the thoracic lymph fluctuate to a certain degree; their increase is accompanied by the fall of the blood resp. lymph sugar, while on the contrary their decrease is associated with the elevation of the blood resp. lymph sugar.

Expenses for this work have been defrayed by a grant from the "Saito Hōonkwai Foundation," for which we express our hearty thanks.

Prof. T. Ku magai. 